\title{
PESANTREN DALAM POLITIK DAN KEBIJAKAN PENDIDIKAN DI INDONESIA
}

\author{
Kharisul Wathoni \\ IAIN Ponorogo \\ kharisulwathoni73@gmail.com
}

\begin{abstract}
A political policy that is carried out within a certain period of time seems to encourage the development of a social system as an effort to maintain the security of the system and political policies. As the government policy given to pesantren as Islamic educational institutions in Indonesia, has had an impact on the development of Islamic education institutions in Indonesia from basic education institutions and even to the formation of higher education institutions that are able to compete with general education institutions. There are 5 characteristics inherent in Islamic boarding schools, namely: pondok, mosque, teaching of classical Islamic books, santri, and kyai. Islamic boarding schools in Indonesia have a very big role, both for the progress of Islam itself and for the Indonesian nation as a whole. Based on existing records, religious education activities in the archipelago have been started since 1596. These religious activities are later known as Islamic boarding schools. Ulama began to realize that the traditional Islamic boarding schools and education systems were no longer suited to the Indonesian climate at that time. Therefore, an idea emerged about the need to develop and renew Islamic education in Indonesia.
\end{abstract}

Keywords: educational policy, Islamic education, pesantren, politics

\begin{abstract}
Abstrak: Suatu kebijaksanaan politik yang dijalankan dalam kurun waktu tertentu tampaknya akan mendorong pengembangan suatu sistem sosial sebagai upaya memelihara yang menjamin berlakunya sistem dan kebijaksanaan politik tersebut. Sebagaimana kebijaksanaan pemerintah yang diberikan kepada pesantren sebagai lembaga pendidikan Islam di Indonesia, memberikan dampak mulai berkembangnya lembaga pendidikan Islam di Indonesia dari lembaga pendidikan dasar dan bahkan sampai terbentuknya lembaga pendidikan perguruan tinggi yang mampu bersaing dengan lembaga pendidikan umum. Karakteristik yang melekat pada pondok pesantren ada 5, yaitu: pondok, masjid, pengajaran kitab-kitab Islam klasik, santri, dan kyai. Pondok Pesantren di Indonesia memiliki peran yang sangat besar, baik bagi kemajuan Islam itu sendiri maupun bagi bangsa Indonesia secara keseluruhan. Berdasarkan catatan yang ada, kegiatan pendidikan agama di Nusantara telah dimulai sejak tahun 1596. Kegiatan agama inilah yang kemudain dikenal dengan nama Pondok Pesantren. Ulama mulai menyadari bahwa sistem pendidikan langgar dan pesantren tradisional sudah tidak begitu sesuai lagi dengan iklim Indonesia saat itu. Oleh karena itu muncul gagasan tentang perlunya melakukan pengembangan dan pembaharuan pendidikan Islam di Indonesia.
\end{abstract}

Kata kunci: Kebijakan pendidikan, pendidikan Islam, pesantren, politik 


\section{PENDAHULUAN}

Pesantren merupakan lembaga pendidikan Islam di Indonesia. Suprayogo menilai perjalanan panjang pendidikan pesantren di Indonesia dapat ditelusuri melalui bentuk-bentuk pendidikan yang diselenggarakan di langgar, masjid atau rumah-rumah penduduk dan guru ngaji yang bersangkutan. Perkembangan selanjutnya, lembaga-lembaga pendidikan yang pada mulanya tidak lebih sekedar berupa kumpulan anak-anak yang belajar pengetahuan agama pada tingkat dasar membaca Al-Qur'an, shalat dan semacamnya, berubah bentuk isinya lembaga-lembaga tersebut telah menjelma menjadi madrasah diniyah, kemudian berkembang menjadi pondok pesantren dan seterusnya dalam bentuk yang lebih akhir berupa madrasah yang bertingkat-tingakat. ${ }^{1}$

Secara yuridis, politik pendidikan di Indonesia dituangkan dalam Undang-undang Sistem Pendidikan. Sampai kini telah diterbitkan 3 (tiga) Undang-undang Sistem Pendidikan Nasional, yaitu Undang-Undang Pokok Pendidikan dan Pengajaran No. 4 Tahun 1950 Undang-undang No. 12 Tahun 1954 yang diterbitkan pada masa orde lama, UU Sisdiknas No. 2 Tahun 1989 pada masa orde baru, dan UU Sisdiknas No. 20 Tahun 2003 pada masa reformasi. Pesantren sebagai cikal bakal lembaga pendidikan yang asli Indonesia baru mendapat pengkuan secara yuridis pada tahun 2003 melalui UU Sisdiknas No. 20 Tahun $2003 .^{2}$

Politik Islam yang dijalankan pemerintah dalam sejarah Indonesia sebelum kemerdekaan memberi suatu latar belakang perkembanagn politik Islam dan khususnya santri pada masa Indonesia merdeka. Beberapa aspek politik Islam mengalami perubahan mendasar setelah kemerdekaan walaupun trauma konsep penuturan semua perkembangan Islam sebagai sumber Inspirasi kekuatan politik yang semula mereupakan kebijaksanaan utama politik kolonial masih sangat berpengaruh terhadap perpolitikan santri. ${ }^{3}$

Suatu kebijaksanaan politik yang dijalankan dalam kurun waktu tertentu tampaknya akan mendorong pengembangan suatu sistem sosial sebagai upaya memelihara yang menjamin berlakunya sistem dan kebijaksanaan politik tersebut. ${ }^{4}$ Sebagaimana kebijaksanaan pemerintah yang diberikan kepada pesantren sebagai lembaga pendidikan Islam di Indonesia, memberikan dampak mulai berkembangnya lembaga pendidikan Islam di Indonesia dari lembaga pendidikan dasar dan bahkan sampai terbentuknya lembaga pendidikan perguruan

\footnotetext{
${ }^{1}$ Khozin, Jejak-jejak Pendidikan Islam di Indonesia, (Malang: UMM Press, 2006), 98.

${ }^{2}$ Ali Anwar, Pembaruan Pendidikan di Pesantren Lirboyo Kediri (Yogyakarta: Pustaka Pelajar, 2010), 35.

${ }^{3}$ Abdul Munir Mulkhan, Runtuhnya Mitos Politik Santri, (Yogyakarta: SIPRESS, 1992), Cet.1, 22.

${ }^{4}$ Ibid., 23.
} 
tinggi yang mampu bersaing dengan lembaga pendidikan umum. Untuk lebih jelasnya lagi, di dalam artikel ini akan di bahas tetang "Pesantren dalam Politik dan Kebijakan Pendidikan di Indonesia”, untuk mengetahui bagaimana sejarah munculnya pesantren, bagaimana karakteristik dan peran pesantren serta bagaimana politik dan kebijakan pesantren di Indonesia.

\section{SEJARAH MUNCULNYA PESANTREN}

Kata pesantren sendiri berasal dari akar kata santri dengan awalan "Pe" dan akhiran "an" berarti tempat tinggal para santri. Dhofier berpendapat bahwa istilah santri berasal dari bahasa Tamil, yang berarti Guru mengaji. ${ }^{5}$ Sedangkan pesantren menurut pengertian dasarnya adalah "tempat belajar para santri", sedangkan pondok berarti "rumah atau tempat tinggal sederhana yang terbuat dari bambu". Di samping itu, "pondok" mungkin juga berasal dari bahasa Arab "fanduk" yang berarti "hotel atau asrama". Ada beberapa istilah yang ditemukan dan sering digunakan untuk menunjuk jenis pendidikan Islam tradisional khas Indonesia atau yang lebih terkenal dengan sebutan pesantren. Di Jawa termasuk Sunda dan Madura, umumnya dipergunakan istilah pesantren atau pondok, di Aceh dikenal dengan istilah dayah atau rangkung atau meunasah, sedangkan di Minangkabau disebut surau. ${ }^{6}$

Adapun pengertian secara terminologi, dapat dikemukakan salah satu pendapat oleh Abdurrahman Wahid, memaknai pesantren secara teknis, a place where santri (student) live, sedangkan Abdurrahman Mas'oed menulis, the word pesantren stems from "santri" which means one who seeks Islamic knowledge. Usually the word pesantren refers to a place where the santri devotes most of his or her time to live in and acquire knowledge, yang berarti kata pesantren berasal dari "santri" yang berarti orang yang mencari pengetahuan Islam, yang pada umumnya kata pesantren mengacu pada suatu tempat, di mana santri menghabiskan kebanyakan dari waktunya untuk tinggal dan memperoleh pengetahuan. Sedangkan pondok pesantren adalah lembaga pendidikan Islam tertua yang merupakan produk budaya Indonesia. Pondok pesantren merupakan "bapak" dari pendidikan Islam di Indonesia, karena adanya tuntutan dan kebutuhan zaman, sesungguhnya pesantren dilahirkan atas kesadaran kewajiban dakwah Islamiah yakni pengembangan dan penyebaran agama Islam. Keberadaan Pesantren di Indonesia dimulai sejak Islam masuk negeri ini dengan mengadopsi sistem pendidikan keagamaan yang sebenarnya telah lama berkembang sebelum kedatangan Islam. Sebagai 1982), 18

5 Zamarkasyi Dhofier, Tradisi Pesantren: Studi Tentang Pandangan Hidup Kiai, (Jakarta: LP3ES, 1999), 40

${ }^{6}$ Hasbullah, Kapita Selekta Pendidikan Islam Di Indonesia, (Jakarta : PT Raja Grafindo Persada, 
lembaga pendidikan yang telah lama berurat akar di negeri ini, pondok pesantren diakui memiliki andil yang sangat besar terhadap perjalanan sejarah bangsa. ${ }^{7}$

Umumnya, suatu pondok pesantren berawal dari adanya seorang kyai di suatu tempat, kemudian datang santri yang ingin belajar agama kepadanya. Setelah semakin hari semakin banyak santri yang datang, timbullah inisiatif untuk mendirikan pondok atau asrama di samping rumah kyai. ${ }^{8}$

Tentang kehadiran pesantren secara pasti di Indonesia pertama kalinya, dimana dan siapa pendirinya, tidak diperoleh keterangan secara pasti. Berdasarkan hasil pendataan yang dilaksanakan Departeman agama pada tahun 1984-1985 diperoleh keterangan bahwa pesantren tertua didirikan pada tahun 1062 di Pamekasan Madura, dengan nama pesantren Jan Tampes II. ${ }^{9}$ Akan tetapi hal ini juga diragukan, karena tentunya ada pesantren Jan Tampes I yang lebih tua. Walaupun demikian, pesantren merupakan lembaga pendidikan Islam tertua di Indonesia yang peran sertanya tidak diragukan lagi, adalah sangat besar bagi perkembangan islam di Nusantara. ${ }^{10}$

Secara terminologis dapat dijelaskan bahwa pendidikan pesantren, dilihat dari segi bentuk dan sistemnya berasal dari India. Sebelum proses penyebaran Islam di Indonesia, sistem tersebut telah digunakan secara umum untuk pendidikan dan pengajaran agama Hindu. Setelah Islam masuk dan tersebar di Indonesia, sistem tersebut kemudian diambil oleh Islam. Istilah pesantren sendiri seperti halnya istilah mengaji, langgar, atau surau di Minangkabau, Rangkang di Aceh bukan berasal dari istilah Arab, melainkan India. ${ }^{11}$

Persoalan historis tentang asal usul pesantren itu bagaimana pun sulit dilepaskan dari sejarah kedatangan Islam ke Nusantara. Islam mulai diperkenalkan ke pulauan Nusantara sejak abad ke $7 \mathrm{M}$ oleh para musaffir muslim melalui perdagangan. Kemudian sejak abad ke 11 M. Islam telah mulai masuk ke kota-kota pantai Nusantara. Bukti lain menunjukkan Islan secara Intensif telah menyebar pada abad ke-13 sampai akhir abad 17. Pada masa itu, berdiri pusat-pusat kekuasaan Islam, seperti di Aceh, Demak, Giri, Ternate dan Gowa. Dari sinilah Islam menyebar ke seluruh Nusantara melalui pedagang, wali, ulama, mubalig dengan mendirikan pesantren, dayah dan surau. Sejak itu, Islam telah menggantikan ajaran Hindu di

\footnotetext{
${ }^{7}$ Amin Haedari, Transformasi Peasntren, (Jakarta: Media Nusantara, 2007), 3.

${ }^{8}$ Rochidin Wahab, Sejarah Pendidikan Islam di Indonesia, (Bandung: CV. Alfabeta, 2004), 153-154.

9 Departemen Agama RI, Nama dan Data Potensi Pondok-pondok Pesantren Seluruh Indonesia, (Jakarta : tt, 1984/1985).

${ }^{10}$ Hasbullah, Kapita Selekta, 41.

${ }^{11}$ Amiruddin Nahrawi, Pembaharuan Pendidikan Pesantren, (Yogyakarta: Gama Media, 2008), 21-22.
} 
Nusantara. Bahkan di Demak sebagai kerajaan Islam di Jawa telah berhasil mengislamkan hampir sebagian masyarakat Demak. ${ }^{12}$

Dengan demikian, pesantren di kenal di bumi Nusantara pada abad 13-17 M, dan di Jawa terjadi pada periode 15-16 M, mengcu data sejarah tentang masuknya Islam ke Nusantara yang bersifat global ini, tentu sangat sulit untuk memastikan dengan tepat kapan dan dimana pesantren pertama didirikan. Sangat mungkin bahwa telah ada di Nusantara sejak 300-400 tahun yang lalu. Ini sekaligus semakin meneguhkan bahwa pesantren telah menjadi bagian dari khazanah budaya bangsa yang mengakar dan berkonstribusi besar dalam penyiaran Islam dan pendidikan sejak dahulu kala. ${ }^{13}$

Pesantren dalam tantangan berbagai zaman telah menunjukkan kulitasnya. Sebagai lembaga pendidikan tertua di Indonesia, pesantren dituntut untuk senantiasa tampil maksimal dan itu telah dibuktikan, sehingga tidak menutup kemungkinan pesantren sebgai sosok lembaga pendidikan yang paling ideal dalam sistem pendidikan nasional. Sebab, walaupun terdapat berbagai kelemahan di dalamnya, paling tidak telah tercukupi potensi-potensi yang di butuhkan untuk memenuhi tuntutan tipologi lembaga pendidikan yang ideal. ${ }^{14}$ Sehingga tanpa adanya pesantren, lembaga pendidikan Islam di Indonesia ini tidak akan berkembang, karena sistem pesantren memberikan warna dalam pendidikan Islam yang terus berkembang dengan inovasi yang disesuaikan dengan kebutuhan masyarakat dan tuntutan zaman.

\section{KARAKTERISTIK DAN PERAN PESANTREN}

Zamarkhsyari Dhofier mengajukan lima karakteristik yang melekat pada pondok pesantren $^{15}$, diantaranya adalah:

1. Pondok

Diantara ciri pokok pesantren memiliki pondokan. Karena itu, lembaga pendidikan Islam ini lebih populer dengan sebutan pondok pesantren, yang artinya keberadaan pondok dalam pesantern yang berfungsi sebagai wadah penggemblengan, pembinaan dan pendidikan serta pengajaran ilmu pengetahuan. Dengan fungsi demikian, maka pondok bagi pesantren jelas memiliki kedudukan yang strategis. Bagi santri untuk menumbuhkan atmosfer kesederhanaan, religiositas yang mendalam, terciptanya iklim akdemik yang kondusif dibidang keilmuan pesantren. Sedangkan bagi kyai atau ustadz,

\footnotetext{
12 Zamarkasyi Dhofier, Tradisi Pesantren, 25.

${ }^{13}$ Amiruddin Nahrawi, Pembaharuan Pendidikan Pesantren, 23.

14 Abuddin Nata, Sejarah Pertumbuhan dan Perkenbangan Lembaga-lembaga Pendidikan Islam di Indonesia (Jakarta: PT Grasindo, 2001), 162.

15 Zamarkasyi Dhofier, Tradisi Pesantren, 44-45.
} 
adanya pondok dapat memudahkan kontrol terhadap santri, termasuk memudakan memproteksi santri dan budaya luar yang tidak kodusif. ${ }^{16}$

Disinilah kyai bersama santrinya bertempat tinggal. Dalam pondok berlangsung sistem pendidikan secara kekeluargaan. Pada awalnya pondok tersebut bukan sematamata dimaksudkan sebagai tempat tinggal atau asrama para santri, untuk mengikuti dengan baik pelajaran yang diberikan kyai, tetapi juga sebagi tempat latihan bagi santri yang bersangkutan agar mampu hidup mandiri dalam masyarakat. Perkembangan selanjutnya, pada masa sekarang pondok tampaknya lebih menonjol fungsinya sebagai tempat pemondokan atau asrama, dan setiap santri dikenakan semacam sewa atau iuran untuk biaya pemiliharaan pondok. ${ }^{17}$

2. Masjid

Di dunia pesantren masjid juga dijadikan sentral segala kegiatan pesantren. Bukan saja kegiatan ritual rutin, tetapi juga sebagai tempat berlangsungnya penyelenggaraan proses belajar mengajar, terutama kegiatan kajian kitab, sorogan, muhadharah, dan lain-lain. Dalam konteks yang luas, masjid merupakan pesantren bagi santri. Bahkan seorang kyai yang hendak merintis pesantren biasanya pertama-tama akan mendirikan masjid disekitar tempat tinggalnya. ${ }^{18}$

Dalam perkembangannya, sesuai dengan jumlah santri dan tingkatan pelajarannya, dibangun tempat atau ruangan-ruangan khusus untuk halaqah-halaqah. Perkembangan terakhir menunjukkan adanya ruangan yang berupa kelas-kelas sebagaimana yang terdapat pada madrasah-madrasah. Namun, masjid tetap sebagai tempat belajar mengajar. ${ }^{19}$

3. Pengajaran kitab-kitab Islam klasik

Pembelajaran kitab-kitab klasik dipandang penting karena dapat menjadikan santri menguasai dua materi sekaligus. Pertama, bahasa Arab yang merupakan bahasa kitab itu sendiri. Kedua, pemahanan/penguasaan muatan dari kitab tersebut. Dengan demikian, seorang santri diharapkan mampu memahami kitab secara baik, sekaligus dapat menerapkan bahasa kitab tersebut menjadi bahasa kesehariannya. ${ }^{20}$

\footnotetext{
${ }^{16}$ Amiruddin Nahrawi, Pembaharuan Pendidikan Pesantren, 24.

${ }^{17}$ Hasbullah, Kapita Selekta, 47.

18 Zamarkasyi Dhofier, Tradisi Pesantren, 49.

19 Ibid., 136.

${ }^{20}$ Amiruddin Nahrawi, Pembaharuan Pendidikan Pesantren, 25-26.
} 
Secara garis besar sistem pengajaran yang dilaksankan di pesantren, dapat dikelompokkan menjadi 3 macam, sebagi berikut: ${ }^{21}$

a. Sorogan: Seorang kyai di dalam memberikan pengajarannya senantiasa berorentasi pada tujuan, selalu berusaha agar santri yang bersangkutan dapat membaca dan mengerti serta mendalami isi kitab.

b. Bandungan, atau sering disebut dengan halaqah, dimana dalam pengajian, kitab dibaca oleh kyai hanya satu, sedangkan para santrinya membawa kitab yang sama, lalu santri mendengarkan dan menyimak bacaan kyai.

c. Weton: Yang berasal dari bahasa Jawa yang diartikan berkala atau berwaktu. Pengajian weton tidak merupakan pengajian rutin harian, tetapi dilaksankan pada saat tertentu, misalnya pada setiap selasai shalat Jum'at saja dan sebagainya.

4. Santri

Terminologi santri erat kaitannya dengan pesantren. Dimana pesantren sebagai tempat orang yang nyantri. Sedangkan santri sebagai peserta didik yang haus akan ilmu pengetahuan dari seorang kyai di pesantren. ${ }^{22}$ Zamarkhsyi Dhofier membuat dua tipologi santri:

a. Santri mukim, yaitu santri yang menetap tinggal bersama kyai dan secara aktif menuntun ilmu dari seorang kyai. Diantara motivasi santri mukim, selain bermaksud menimba ilmu langsung dari kyai, juga bercita-cita memperbaiki akhlak.

b. Santri kalong, yaitu seorang murid yang bersasal dari sekitar pondok atau lainnya yang pola belajarnya tidak menetap di pesantren, melainkan semata-mata belajar dan langsung pulang ke rumah atau tempat tinggalnya setiap selesai belajar.

Yang membedakan antara pesantren besar dengan pesantren kecil biasanya terletak pada pebandingan antara kedua kelompok santri tersebut. Biasanya pesantren besar memiliki jumlah santri mukim yang lebih banyak dibandinkan dengan jumlah snatri di pesantren kecil. ${ }^{23}$

5. Kyai

${ }^{21}$ Hasbullah, Kapita Selekta, 51-52.

${ }^{22}$ Amiruddin Nahrawi, Pembaharuan Pendidikan Pesantren, 26.

${ }^{23}$ Hasbullah, Kapita Selekta, 49. 
Pada dasarnya gelar seorang kyai lebih ditujukan kepada seseorang yang memiliki pengetahuan agama Islam secara mendalam, sekaligus memiliki lembaga pendidikan pesantren. Suatu lembaga pendidikan Islam disebut pesantren apabila memiliki tokoh sentral yang disebut kyai. Dari aspek kepemimpinan pesantren kyai memegang kekuasaan yang hampir-hampir mutlak. Kyai berperan penting dalam mengembangkan dan menggerakkan pesantren. Oleh karena itu, kyai berdimensi ganda, yaitu sebagai pemimpin pondok, sekaligus juga sebagai pemilik pondok itu sendiri. ${ }^{24}$

K. H. Ali Maksum memberikan data untuk mengetahui macam-macam pola pondok pesantren seperti yang terlihat dalam tabel berikut: ${ }^{25}$

Table 1. Karakteristik Pondok Pesantren

\begin{tabular}{|c|c|c|c|}
\hline No. & Sarana & $\begin{array}{c}\text { Metode } \\
\text { Mengajar }\end{array}$ & Keterangan \\
\hline 1. & $\begin{array}{l}\text { Masjid } \\
\text { Rumah Kyai }\end{array}$ & $\begin{array}{l}\text { Weton dan } \\
\text { sorogan }\end{array}$ & $\begin{array}{l}\text { Pesantren ini masih bersifat sederhana } \\
\text { dimana kyai mempergunakan masjid atau } \\
\text { rumahnya sendiri untuk tempat mengajar. } \\
\text { Dalam pola ini santri hanya datang dari } \\
\text { daerah sekitar pesantren, namun mereka } \\
\text { telah mempelajari ilmu agama secara } \\
\text { kontinyu dan sistematis. }\end{array}$ \\
\hline 2. & $\begin{array}{l}\text { Masjid } \\
\text { Rumah Kyai } \\
\text { Pondok }\end{array}$ & $\begin{array}{l}\text { Weton dan } \\
\text { sorogan }\end{array}$ & $\begin{array}{l}\text { Dalam hal ini pesantreb telah memiliki } \\
\text { pndok atau asrama yang disediakan bagi para } \\
\text { santri yang datang dari daerah lain. }\end{array}$ \\
\hline 3. & $\begin{array}{l}\text { Masjid } \\
\text { Rumah Kyai } \\
\text { Pondok } \\
\text { Madrasah }\end{array}$ & $\begin{array}{ll}\text { Weton dan } \\
\text { klasikal }\end{array}$ & $\begin{array}{l}\text { Pesantren yang memberikan fasilitas } \\
\text { pendidikan di madrasah dengan sistem kelas. } \\
\text { Adakalanya murid madrasah dengan sistem } \\
\text { kelas. Adakalanya murid madrsah itu datang } \\
\text { dari daerah pesantren itu sendiri. Disamping } \\
\text { ada madrasah, sistem sorogan masih tegas } \\
\text { dilakukan pada waktu yang ditentukan oleh } \\
\text { kyai atau pengasuh pondok. }\end{array}$ \\
\hline 4. & $\begin{array}{l}\text { Masjid } \\
\text { Rumah Kyai } \\
\text { Pondok } \\
\text { Madrasah } \\
\text { Tempat } \\
\text { ketrampilan }\end{array}$ & $\begin{array}{l}\text { klasikal, } \\
\text { sorogan dan } \\
\text { latihan } \\
\text { ketrampilan }\end{array}$ & $\begin{array}{l}\text { Disamping melakukan pada pola (3), santri } \\
\text { juga diberi kesempatan untuk melatih diri } \\
\text { dalam beberrapa ketrampilan. Seperti, } \\
\text { peternakan, kerajinan tangan, toko koperasi, } \\
\text { sawah dan ladang. }\end{array}$ \\
\hline
\end{tabular}

${ }^{24}$ Ali Maksum, "Ulama Kita”dalam Bangkit, (Pekalongan: Udin Putra, 1983), no. 37 Th. IV, 23.

25 Amiruddin Nahrawi, Pembaharuan Pendidikan Pesantren, 104-105. 


\begin{tabular}{|c|c|c|c|}
\hline 5. & $\begin{array}{l}\text { Masjid } \\
\text { Rumah Kyai } \\
\text { Pondok } \\
\text { Madrasah } \\
\text { Tempat } \\
\text { ketrampilan } \\
\text { Universitas } \\
\text { Gedung } \\
\text { pertemuan } \\
\text { Tempat } \\
\text { olahraga } \\
\text { Sekolah umum }\end{array}$ & $\begin{array}{l}\text { klasikal, } \\
\text { sorogan } \\
\text { sekolah } \\
\text { berijazah dan } \\
\text { perguruan } \\
\text { tinggi }\end{array}$ & $\begin{array}{l}\text { Pesantren ini sering disebut pesantren } \\
\text { modern, memiliki fasilitas penunjang dan } \\
\text { ada pula sekolah-sekolah umum ataupun } \\
\text { madrasah untuk masyarakat sekitar. Pada } \\
\text { umumnya pesantren model ini menggunakan } \\
\text { fase pembinaan yang terakreditasi melalui } \\
\text { ijazah. }\end{array}$ \\
\hline
\end{tabular}

Pondok Pesantren di Indonesia memiliki peran yang sangat besar, baik bagi kemajuan Islam itu sendiri maupun bagi bangsa Indonesia secara keseluruhan. Berdasarkan catatan yang ada, kegiatan pendidikan agama di Nusantara telah dimulai sejak tahun 1596. Kegiatan agama inilah yang kemudain dikenal dengan nama Pondok Pesantren. Bahkan dalam catatan Howard M. federspiel- salah seorang pengkaji ke-Islaman di Indonesia, menjelang abad ke12 pusat-pusat studi di Aceh dan Palembang (Sumatra), di Jawa Timur dan di Gowa (Sulawesi) telah menghasilkan tulisan-tulisan penting dan telah menarik santri untuk belajar. ${ }^{26}$

Kini di tengah-tengah sistem Pendidikan Nasional yang selalu berubah-rubah dalam jeda waktu yang tidak lama, apresiasi masyarakat Islam Indonesia terhadap pesantren makin hari makin besar, pesantren yang asalnya sebagai Rural Based Institusion kemudian berkembang menjadi lembaga pendidikan urban. Lihatlah kemunculan sejumlah pesantren kota seperti di Jakarta, Bandung, Medan, Pekanbaru, Yogjakarta, Malang, Semarang, Ujung Pandang, atau sub-urban Jakarta seperti Parung, Cilangkap. Atau misalnya pesantren yang muncul pada tahun 1980-an seperti Pesantren Darun Najah, Cianjur, dan Ashidiqiyah di Jakarta; Pesantren Nurul hakim, al-Kautsar, Darul Arafah di Medan, Mustafawiyyah Purba Baru di Mandiiling-Natal dan ada disekitarnya sekarang, Darul Hadits Hutabaringin, Darul Ikhlas di Dalan-lidang, dan Pesantren Muara Mais, Darul Hikmah di Pekan Baru dan lainlain.

Pesantren sebagai lembaga pendidikan yang tumbuh dan berkembang di tengahtengah masyarakat sekaligus memadukan 3 unsur pendidikan yang amat penting yaitu: ibadah

${ }^{26}$ Irfan Hielmy, Wancana Islam (ciamis: Pusat Informasi Pesantren,2000), 120. 
dalam menanamkan iman, tabligh untuk penyebaran ilmu dan amal untuk menunjukkan kegiatan masyarakat dalam kehidupan sehari-hari. ${ }^{27}$

\section{POLITIK DAN KEBIJAKAN PESANTREN}

Alin Anwar mengutip dari Benda, bahwa modernisasi pendidikan kolonial yang memberikan inspirasi gerakan pembaharuan pendidikan Islam. Dua sistem pendidikan tersebut kemudian melahirkan dua cabang komunitas Islam santri dan sekuler yang kemudian menempati posisi birokrat. Dua cabang inilah yang kemudian melatarbelakangi berbagai konflik justru diantara kelompok umat sendiri. ${ }^{28}$

Elite santri terdiri dari para ulama, kyai dan mubaligh yang sesuai dengan lingkungan geografis dan latar belakang pendidikannya banyak yang bekerja sebagai petani dan pedagang. Pekerjaan elite dan juga komunitas santri lebih banyak memberikan peluang mereka bertindak bebas dan mandiri, tidak demikian halnya setelah proses modernisasi pendidikan Islam mereka mulai memasuki lapangan birokrasi dan pegawai negeri. ${ }^{29}$

Kecendrungan elite santri modern melibatkan diri dalam birokrasi mengakibatkan ketergantungan polotik Islam setelah pemerintahan Orde Baru. Demikian pula sistem pendidikan Islam modern telah mendesak posisi dan fungsi pendidikan Islam tradisional seperti pesantren dan madrasah yang kemudian semakin memperkecil komposisi populasi elite santri tradisional yang semula bertindak sebagai penerjemah ide dan gagasan perjuangan Islam yang bersumber ajaran Islam. Demikian pula telah mendesak posisi elite santri yang mampu brtindak bebas dan mandiri. Hal tersebut antara lain mengakibatkan hilangnya referensi sosial umat. ${ }^{30}$

Posisi politik dalam perjuangan Islam kemudian tergeser dengan munculnya gerakan dakwah sebagai alternatif gerakan politik dalam realisasi ide perjuangan Islam. perkembangan baru tersebut mendorong timbulnya perkembangan baru pemikiran politik di kalangan anak muda santri sekitar tahun 1968. Perkembangan pemikiran tersebut ditandai dengan munculnya isu sekularisasi ajaran Islam. ${ }^{31}$

Perilaku politik santri yang bersumber pada teologi-Politiknya terjadi dalam proses interaksi antara pemahaman santri terhadap ajaran agamanya dan realitas politik sebagai akibat kebijaksanaan politik pemerintah yang sedang berkuasa. Oleh karena itu perlu sekali

\footnotetext{
${ }^{27}$ Rochidin Wahab, Sejarah Pendidikan Islam di Indonesia, (Bandung: Alfabeta, CV, 2004), 31-32.

${ }^{28}$ Ali Anwar, Pembaruan Pendidikan di Pesantren Lirboyo Kediri, 26.

${ }^{29}$ Ibid., 27.

${ }^{30}$ Ibid., 27-28.

${ }^{31}$ Ibid., 33.
} 
dikaji politik pemerintah terhadap umat Islam yang ditempatkan sebagai petunjuk perubahan atau perkembangan teologi-politik santri. ${ }^{32}$

Tujuan terpenting pendidikan pesantren adalah membangun moralitas agama santri dengan pengalamannya. Dalam hal ini berarti yang menjadi fokus tujuan pendidikan pesantren adalah memberdayakan santri. bergerak dengan tujuan yang jelas, dan memahami fungsinya sebagai agen perubahan dan pewaris budaya, pesantren memang tidak hanya memfokuskan diri pada pencetakan mubaligh-mubaligh berkualitas, setelah terjun ke masyarakat, santri harus menyebar ke segala bidang kehidupan. Dalam konteks demikian, kelengkapan pengetahuan menjadi semakin penting. ${ }^{33}$

Sistem pendidikan pesantren didasarkan atas dialog yang terus menerus antara kepercayaan terhadap ajaran dasar agama yang diyakini memiliki nilai kebenaran mhtlak dan realitas sosial yang memiliki nilai kebenaran relatif. Moralitas inilah yang kelak membentuk pandangan hidup santri. ${ }^{34}$

Sistem pendidikan Belanda yang kala itu jauh lebih maju dan lebih modern, tampaknya juga menjadi salah satu pemicu munculnya kesadaran baru untuk melakukan perubahan-perubahan dalam pendidikan Islam. Para ulama mulai menyadari bahwa sistem pendidikan langgar dan pesantren tradisional sudah tidak begitu sesuai lagi dengan iklim Indonesia saat itu. Oleh karena itu muncul gagasan tentang perlunya melakukan pengembangan dan pembaharuan pendidikan Islam di Indonesia. Realisasinya, sistem pendidikan madrasah yang berkembang di dunia Islam pada umumnya dan sistem sekolah yang dikembangkan oleh pemerintah kolonial mulai dimasukkan ke dalam sistem pendidikan pesantren. Pada gilirannya sistem pengajaran halaqah bergerser ke arah sistem klasikal dengan unit-unit kelas dan sarana prasarana sebagaimana dalam kelas-kelas pada sekolahsekolah. ${ }^{35}$ Sehingga dari situlah lembaga pendidikan Islam di Indonesia mulai berkembang dan terus mengalami perubahan yang menjadi lebih baik dengan tetap perpedoman kepada alQur'an dan hadis sebagai sumber dan dasar agama Islam.

\footnotetext{
${ }^{32}$ Ibid., 93-94.

${ }^{33}$ Mansur, Moralitas Pesantren, (Yogyakarta: Safiria Insania Press, 2004), 27-28.

34 Ibid., 29.

${ }^{35}$ Mahmud Yunus, Sejarah Pendidikan Islam di Indonesia, (Jakarta: Hidakarya Agung, 1985), 62.
} 


\section{KESIMPULAN}

Persoalan historis tentang asal usul pesantren itu bagaimana pun sulit dilepaskan dari sejarah kedatangan Islam ke Nusantara. Islam mulai diperkenalkan ke pulauan Nusantara sejak abad ke $7 \mathrm{M}$ oleh para musaffir muslim melalui perdagangan. Kemudian sejak abad ke 11 M. Islam telah mulai masuk ke kota-kota pantai Nusantara. Bukti lain menunjukkan Islam secara Intensif telah menyebar pada abad ke-13 sampai akhir abad 17.

Karakteristik yang melekat pada pondok pesantren ada 5, yaitu: pondok, masjid, pengajaran kitab-kitab Islam klasik, santri, dan kyai. Pondok Pesantren di Indonesia memiliki peran yang sangat besar, baik bagi kemajuan Islam itu sendiri maupun bagi bangsa Indonesia secara keseluruhan. Berdasarkan catatan yang ada, kegiatan pendidikan agama di Nusantara telah dimulai sejak tahun 1596. Kegiatan agama inilah yang kemudain dikenal dengan nama Pondok Pesantren.

Sistem pendidikan Belanda yang kala itu jauh lebih maju dan lebih modern, tampaknya juga menjadi salah satu pemicu munculnya kesadaran baru untuk melakukan perubahan-perubahan dalam pendidikan Islam. Para ulama mulai menyadari bahwa sistem pendidikan langgar dan pesantren tradisional sudah tidak begitu sesuai lagi dengan iklim Indonesia saat itu. Oleh karena itu muncul gagasan tentang perlunya melakukan pengembangan dan pembaharuan pendidikan Islam di Indonesia.

\section{DAFTAR PUSTAKA}

Anwar, Ali. Pembaruan Pendidikan di Pesantren Lirboyo Kediri. Yogyakarta: Pustaka Pelajar, 2010.

Departemen Agama RI. Nama dan Data Potensi Pondok-pondok Pesantren Seluruh Indonesia. Jakarta: tt, 1984/1985.

Dhofier, Zamarkhsyi. Tradisi Pesantren: Studi Tentang Pandangan Hidup Kiai. Jakarta: LP3ES, 1982.

Haedari, Amin. Transformasi Peasntren. Jakarta: Media Nusantara, 2007.

Hasbullah. Kapita Selekta Pendidikan Islam Di Indonesia. Jakarta: PT Raja Grafindo Persada, 1999.

Hielmy, Irfan. Wancana Islam. Ciamis: Pusat Informasi Pesantren, 2000.

Khozin. Jejak-jejak Pendidikan Islam di Indonesia. Malang: UMM Press, 2006.

Maksum, Ali. “Ulama Kita”dalam Bangkit. Pekalongan: Udin Putra, 1983. no. 37 Th. IV. 
Mulkhan, Abdul Munir. Runtuhnya Mitos Politik Santri. Yogyakarta: SIPRESS, 1992. Cet.1.

Nahrawi, Amiruddin. Pembaharuan Pendidikan Pesantren. Yogyakarta: Gama Media, 2008.

Nata, Abuddin. Sejarah Pertumbuhan dan Perkenbangan Lembaga-lembaga Pendidikan Islam di Indonesia. Jakarta: PT Grasindo, 2001.

Wahab, Rochidin. Sejarah Pendidikan Islam di Indonesia. Bandung: Alfabeta, CV, 2004.

Yasin, Fatah A. Dimensi-dimensi Pendidikan Islam. Malang: UIN Malang Press, 2008.

Yunus, Mahmud. Sejarah Pendidikan Islam di Indonesia. Jakarta: Hidakarya Agung, 1985. 